
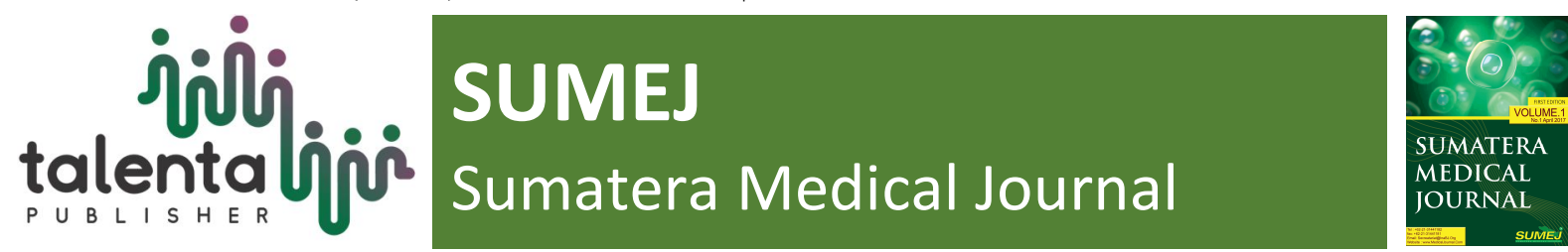

\title{
Comparison Pai-1 Level in Type 2 Diabetes Mellitus with and Without Diabetic Foot Ulcer
}

\author{
Alfi Dewi Sholaht ${ }^{*}$, Dairion Gatot ${ }^{2}$, Savina Handayani ${ }^{3}$, Andri Iskandar \\ Mardia $^{4}$, Santi Syafril 5 \\ 1,2,3,4,5 Department of Internal Medicine, Faculty of Medicine Universitas Sumatera Utara, Indonesia
}

\begin{abstract}
In type 2 diabetes mellitus, there are changes in hemostasis components, including overexpression of PAI-1. By these facts, the authors are interested in conducting the study of PAI-1 level in diabetic patients with and without foot ulcer. Methods: The sample of this research was collected cross-sectionally on 20 type 2 diabetic patients with foot ulcer and 20 without foot ulcer. Blood samples were taken to measure serum PAI-1 level, complete blood count and hemostasis screening test. Results: Statistical analysis showed there are significant differences in hemoglobin, trombosit, Fibrinogen and D-dimer levels in the ulcer and nonulcer groups but no significant difference in PAI-1 level. Conclusions: No higher PAI - 1 level were found in diabetic foot ulcer group than those without diabetic foot ulcer. There was no significant difference between PAI-1 level and grade of diabetic foot ulcer.
\end{abstract}

Keyword: Thrombosis, Diabetes Mellitus, Diabetic Food Ulcer, PAI-1

Abstrak. Pada diabetes mellitus tipe 2, ada perubahan dalam komponen hemostasis, termasuk overekspresi PAI-1. Dengan fakta-fakta ini, penulis tertarik untuk melakukan penelitian tingkat PAI-1 pada pasien diabetes dengan dan tanpa ulkus kaki. Metode: Sampel penelitian ini dikumpulkan secara cross-sectional pada 20 pasien diabetes tipe 2 dengan ulkus kaki dan 20 tanpa ulkus kaki. Sampel darah diambil untuk mengukur kadar serum PAI1, hitung darah lengkap dan tes skrining hemostasis. Hasil: Analisis statistik menunjukkan ada perbedaan yang signifikan dalam kadar hemoglobin, trombosit, Fibrinogen dan D-dimer pada kelompok ulkus dan non-ulkus tetapi tidak ada perbedaan yang signifikan dalam tingkat PAI-1. Kesimpulan: Tidak ada tingkat PAI - 1 yang lebih tinggi ditemukan pada kelompok ulkus kaki diabetik dibandingkan dengan mereka tanpa ulkus kaki diabetik. Tidak ada perbedaan yang signifikan antara tingkat PAI-1 dan tingkat ulkus kaki diabetik.

Kata Kunci: Trombosis, Diabetes Mellitus, Ulkus Makanan Diabetes, PAI-1

Received 23 March 2018 | Revised 30 June 2018 | Accepted 18 September 2018

\section{Introduction}

Nowadays, researches and data about changes in PAI-1 level in type 2 diabetic patients are still limited to type 2 diabetes mellitus and diabetic foot. By this reason, we are interested to conduct a research of PAI-1 level in type 2 diabetic patients, with and without diabetic foot ulcer. The special purpose of this research is to compare the level of Plasminogen Activator Inhibitor-1 in

\footnotetext{
*Corresponding author at: Faculty of Medicine, Jalan Doktor Mansyur No.5 Kampus USU Padang Bulan, Medan, Sumatera Utara 20155
} 
type 2 diabetic patients with and without diabetic foot ulcer and the main purpose is to differentiate coagulation status of type 2 diabetic patients with and without diabetic foot ulcer.

\section{Methodology}

This is a cross sectional descriptive analytic study which was conducted at May-July 2017 in RSUP H Adam Malik Medan on 20 hospitalized type 2 diabetic patients with diabetic foot according to Wagner criteria and 20 hospitalized type 2 diabetic patients without diabetic foot. All of them fulfills inclusion and exclusion criteria and blood samples were withdrawn for PAI-1 serum level, complete blood count and hemostasis screening test.

This research data will be analyzed by using SPSS (Statistical Product and Science Service) for Windows.

\section{Results}

In this study, the subjects are diabetic patients with and without diabetic foot ulcer, 20 patients each. The results of this research are explained by the following tables.

Table 1 does not show significant differences between the two groups of age and gender $(\mathrm{p}>$ 0.05). But for laboratory results, by statistic means, it shows significant differences of hemoglobin, platelet, Fibrinogen and D-dimer between diabetic foot ulcer and non-ulcer groups $(\mathrm{p}<0.05)$. Grade 4 and grade 3 were in the top lists by $50 \%$ and $35 \%$. The least was grade 5 (15\%). This study obtains coagulation state of 20 diabetic patients with diabetic foot ulcer 14 patients $(70 \%)$ with hypercoagulative and 6 patients $(30 \%)$ with hypocoagulative respectively.

Table 1. Study Subjects Characteristics

\begin{tabular}{lccc}
\hline Characteristics & \multicolumn{3}{c}{ Study Subjects } \\
\hline & $\begin{array}{c}\text { Diabetic Foot Ulcer } \\
(\mathbf{n}=\mathbf{2 0}) \\
\text { Mean } \pm \text { SD }\end{array}$ & $\begin{array}{c}\text { Without Diabetic Foot } \\
\text { Ulcer } \\
(\mathbf{n}=\mathbf{2 0})\end{array}$ & P Value \\
& Mean \pm SD & \\
\hline Age (Years) & $5(25 \%)$ & $3(15 \%)$ & \\
$40-49$ & $11(55 \%)$ & $10(50 \%)$ & $0,493^{\mathrm{a}}$ \\
$50-59$ & $4(20 \%)$ & $7(35 \%)$ & \\
$60-69$ & & $10(50 \%)$ & $0,337^{\mathrm{b}}$ \\
\hline Gender & $13(65 \%)$ & $10(50 \%)$ & \\
Man & $7(35 \%)$ & & \\
Woman & & & \\
\hline
\end{tabular}




\begin{tabular}{lcc}
\hline Ulcer Grade & \\
0 & 0 & $20(100 \%)$ \\
3 & $7(35 \%)$ & 0 \\
4 & $10(50 \%)$ & 0 \\
5 & $3(15 \%)$ & 0
\end{tabular}

\begin{tabular}{lccc}
\hline Complete Blood Count & & & \\
$\mathrm{Hb}(\mathrm{g} / \mathrm{dL})$ & $10.7 \pm 1.7$ & $13,1 \pm 1,7$ & $0,001^{\mathrm{d}}$ \\
$\operatorname{Trombosit}\left(\times 10^{3} / \mathrm{mm}^{3}\right)$ & $381 \pm 122$ & $303 \pm 110$ & $0,041^{\mathrm{d}}$ \\
\hline Fibrinogen $(\mathrm{mg} / \mathrm{dL})$ & $445 \pm 215$ & $291 \pm 90$ & $0,009^{\mathrm{c}}$ \\
D-Dimer(ng/mL) & $648 \pm 313$ & $404 \pm 302$ & $0,017^{\mathrm{d}}$
\end{tabular}

\section{Coagulation State}

Hypercoagulative $\quad 14(70 \%)$

${ }^{a}$ Fisher exact test $\quad{ }^{b}$ Chi-square test $\quad{ }^{c}$ Mann-Whitney test ${ }^{d}$ T-test

Table 2 shows PAI-1 level in diabetic foot ulcer patients is in median 14,06 $\mathrm{ng} / \mathrm{mL}$ lower than without ulcer PAI-1 group (16.71 ng/mL). Mann-Whitney Test shows no significant difference of PAI-1 level between diabetic foot ulcer and without ulcer groups ( $p>0.05)$. PAI-1 level in diabetic foot ulcer patients is in median $12,51 \mathrm{ng} / \mathrm{mL}$ with hypercoagulative and $20,59 \mathrm{ng} / \mathrm{mL}$ with hypocoagulative. Mann-Whitney Test shows no significant difference of PAI-1 level in diabetic foot ulcer with hypercoagulative and hypocoagulative groups $(\mathrm{p}>0.05)$.

Table 2. Differences of Pai Level $(\mathrm{Ng} / \mathrm{Ml})$ in Type 2 Diabetes Mellitus with and without Diabetic Foot Ulcer and Correlation of Coagulation State and Pai-1 Level

\begin{tabular}{lcccccc}
\hline & With & Without & & $\begin{array}{c}\text { Hypercoagulative } \\
\text { With Ulcer }\end{array}$ & $\begin{array}{c}\text { Hypocoagulative } \\
\text { With Ulcer }\end{array}$ & \\
& Ulcer & Ulcer & $\boldsymbol{P}$ & $\mathbf{n}=\mathbf{1 4}$ & $\mathbf{n}=\mathbf{6}$ & $\boldsymbol{P}$ \\
& $\mathbf{n = 2 0}$ & & $\mathbf{n}$ & & \\
& & & & & & \\
$\mathrm{PAI}-1$ & 14,06 & 16,71 & & 12,51 & 20,59 & 0,509 \\
$(\mathrm{ng} / \mathrm{mL})$ & $7,25-$ & $(2,62-$ & 0,957 & $(7,25-120,01)$ & $(2,62-138,71)$ & \\
& $38,71)$ & $63,47)$ & & & & \\
\hline
\end{tabular}

Table 3 shows no significant correlation between the grading of diabetic foot ulcer and PAI-1 level. $(\mathrm{r}=0.16 ; \mathrm{p}=0.505)$. 
Table 3. Correlation Of Diabetic Foot Ulcer Grades And Pai-1 Level

\begin{tabular}{cccccc}
\hline & $\begin{array}{c}\text { Grade 3 } \\
(\mathbf{n = 7})\end{array}$ & $\begin{array}{c}\text { Grade 4 } \\
(\mathbf{n = 1 0})\end{array}$ & $\begin{array}{c}\text { Grade 5 } \\
(\mathbf{n = 3})\end{array}$ & $\boldsymbol{P}$ & $\mathbf{r}$ \\
\hline \multirow{3}{*}{ PAI-1 $(\mathrm{ng} / \mathrm{mL})$} & 12,48 & 35,26 & 9,05 & & \\
& $(8,44-20,89)$ & $(7,25-138,71)$ & $(8,50-137,35)$ & 0,505 & 0,16 \\
\hline
\end{tabular}

\section{Discussion}

This study shows PAI-1 level in diabetic foot ulcer patients is in median 14,06 ng/mL lower than without ulcer PAI-1 group (16.71 ng/mL). Mann-Whitney Test shows no significant difference of PAI-1 level between diabetic foot ulcer and without ulcer groups $(p>0.05)$. Schneider and Sobel in 2012 found that PAI-1 level is increased in type 2 diabetes mellitus patients [1]. In contrast, Kulwas et al in 2016 found that PAI-1 concentration in diabetic foot, type 2 diabetes without vascular complication and control group show no significant statistical differences [2]. In contrast to a study by Rautio A et al in 2016 in Sweden who found after 10 years observed that level of PAI-1 increased statistically significantly in non-diabetic and type 1 diabetes melitus subjects, in contrast to type 2 diabetes melitus which decreased PAI-1 level statistically significant in type 2 diabetes mellitus [3].

The result of this study shows no significant correlation between grade of diabetic foot ulcer and PAI-1 level, which agrees with Kulwas et al study that shows no significant differences between PAI-1 concentration and various of diabetic foot grading by Wagner's criteria [2].

As stated above, diabetes mellitus is involed in prothrombotic condition [4]. Increasing PAI-1 level in diabetes patient is believed to be multifactorial. The combination of hyperinsulinemia, hypertriglyceridemia and hyperglycemia increase PAI-1 concentration in the blood. PAI-1 is a linear glycoprotein produced by endothelium functioning as primary inhibitor of t-PA and u-PA activities on fibrinolysis. Bonding of PAI-1 in the plasma and extracellular matrix is stabilized by vitronectin. Only few PAI-1 can be found in the normal fresh plasma compared to fresh blood containing platelet, due to vitronectin is contained in platelet which supports PAI-1 as the main factor of resistance properties of thrombus containing much platelet will be more resistant to thrombolysis process [5].

The limitations of this study are it is conducted in only one health center, there is no data on how long the patient had type 2 diabetes mellitus and does not analyse the length of morbidity and whether the diabetes is controlled or not. Previously, Rubeaan et al found that the duration of morbidity and $\mathrm{HbAlc}$ is significantly higher in diabetic foot ulcer, gangrene and amputation compared to nonaffected patients [6]. Besides, there is no inflammatory marker data that can be used as predictors of severity of diabetic foot ulcers. And there is no examination of other factors that may affect coagulation, such as albumin. 
In conclusion, no higher PAI-1 level were found in diabetic foot ulcer group than those without diabetic foot ulcer. There was no significant difference between PAI-1 level and grade of diabetic foot ulcer.

\section{REFERENCES}

[1] D. J. Schneider and B. E. Sobel, "PAI-1 and diabetes: a journey from the bench to the bedside," Diabetes Care, vol. 35, no. 10, pp. 1961-1967, 2012.

[2] A. Kulwas et al., "Tissue plasminogen activator (t-PA) and plasminogen activator inhibitor type 1 (PAI-1) in diabetic foot syndrome," Advances in medical sciences, vol. 62, no. 1, pp. 87-91, 2017.

[3] A. Rautio, K. Boman, J. W. Eriksson, and M. K. Svensson, "Markers of fibrinolysis may predict development of lower extremity arterial disease in patients with diabetes: A longitudinal prospective cohort study with 10 years of follow-up," Diabetes and Vascular Disease Research, vol. 13, no. 3, pp. 183-191, 2016.

[4] P. J. Grant, "Diabetes mellitus as a prothrombotic condition," Journal of internal medicine, vol. 262, no. 2, pp. 157-172, 2007.

[5] B. R. Binder et al., "Plasminogen activator inhibitor 1: physiological and pathophysiological roles," Physiology, vol. 17, no. 2, pp. 56-61, 2002.

[6] K. Al-Rubeaan et al., "Diabetic foot complications and their risk factors from a large retrospective cohort study," PloS one, vol. 10, no. 5, p. e0124446, 2015. 